Tayfun Bilgin

Officials and Administration in the Hittite World 


\section{Studies in Ancient Near Eastern Records}

General Editor:

Gonzalo Rubio

Editors:

Nicole Brisch, Petra Goedegebuure, Markus Hilgert, Amélie Kuhrt, Peter Machinist, Piotr Michalowski, Cécile Michel, Beate Pongratz-Leisten, D. T. Potts, and Kim Ryholt

\section{Volume 21}




\section{Tayfun Bilgin}

Officials and

Administration in

the Hittite World

DE GRUYTER 
ISBN 978-1-5015-1662-7

e-ISBN (PDF) 978-1-5015-0977-3

e-ISBN (EPUB) 978-1-5015-0976-6

ISSN 2161-4415

Library of Congress Control Number: 2018954471

Bibliographic information published by the Deutsche Nationalbibliothek

The Deutsche Nationalbibliothek lists this publication in the Deutsche Nationalbibliografie; detailed bibliographic data are available in the Internet at http://dnb.dnb.de.

(c) 2018 Walter de Gruyter GmbH, Berlin/Boston Typesetting: Dörlemann Satz, Lemförde

Printing and binding: CPI books $\mathrm{GmbH}$, Leck

www.degruyter.com 